\title{
Species Composition and Abundance of Freshwater Fishes in Selected Rivers of Johor, Malaysia
}

\author{
Vincent K.K.Chow ${ }^{1}$, Mohd Ismid Mohd Said ${ }^{1}$, Maketab Mohamed ${ }^{1}$ and Shaikhah Sabri ${ }^{2}$
}

\begin{abstract}
A total of 1124 adult and juvenile individuals, representing 35 species from 13 families were collected in the four rivers of Johor. Each river represents a different of land use; Sungai Mengkibol is an urban river, Sungai Madek is associated with logging activities, the downstream section of Sungai Dengar for agricultural activities and it's middle section which is located at the foot of Gunung Berlumut as a reference station under pristine forest condition. The families represented in the samplings was dominated by Cyprinidae with 20 species $(54.29 \%)$, followed by Mastacembelidae with three species $(8.57 \%)$, Channidae and Hemiramphidae with 2 species each $(5.71 \%)$. The other families were represented by one species each from Bagridae, Cichlidae, Claridae, Cobitidae, Gobiidae, Loricariidae, Poecilidae, Sisoridae and Synbranchidae $(2.86 \%$ each). The highest number of fish were collected at Sungai Dengar station (376 individuals) followed by Sungai Ulu Dengar (306 individuals), Sungai Madek (238 individuals) and Sungai Mengkibol (204 individuals). Although the number of fish among the rivers were not statistically different ( $\mathrm{p}=$ $0.138, \mathrm{p}>0.05$ ), species diversity was significantly different according to river characteristics. Sungai Ulu Dengar has the highest number of species with 22 species, followed by Sungai Dengar with 21 species and Sungai Madek with 19 species. The lowest number of species was recorded at Sungai Mengkibol with 11 species. Water quality parameters like dissolved oxygen, turbidity and temperature show positive correlation with the species diversity. Therefore, it can be concluded that healthy river support high diversity of fish species.
\end{abstract}

Index Terms - Fish diversity, fish species, freshwater fish, Johor rivers.

\section{INTRODUCTION}

There are 189 river systems in Malaysia with 89 in peninsular Malaysia and the balance located in East Malaysia [1]. However, $42 \%$ of the rivers systems have been classified as polluted, mostly due to surface runoff, discharge of sewage and industrial effluent [2]. As the human population increases, the pressure on the utilization of natural resources increases in tandem. Progressive industrialization may lead to habitat destruction, degradation and fragmentation which pose serious threats to aquatic environment and its resource potential [3].

However, freshwater resources are not only over-exploited or poorly managed in the world but also ecologically degraded [4].

Vincent K.K.Chow is with Department of Environment, Faculty of Civil Engineering, Universiti Teknologi Malaysia, 81310 Johor Bahru, Johor

Said, M. I. M. is with Department of Environment, Faculty of Civil Engineering, Universiti Teknologi Malaysia, 81310 Johor Bahru, Johor

Mohamed, M. is with Faculty of Chemical Engineering, Universiti Teknologi Malaysia, 81310 Johor Bahru, Johor.

Sabri, S. is with Tradewinds Plantation Berhad.
Encroachments along river systems and watersheds have brought dire results to these freshwater resources due to the activities of humans.

For the many rivers and streams that were once fresh and pristine, but have now become polluted by sullage, effluents, xenobiotic and silt loads. Where once they were the symbol of freshness, continuity and eternity, they are now the focus of many countries and authorities in either cleaning them up or keeping pollution at bay. Though once such pristine waterways were a blessing for Mankind, they are today a sink for his rubbish, pollutants and sewerage. What was once a common source of free protein for the poor and rural folks, fishes have been slowly wiped out by polluted water [5].

As a part of the river ecosystem, fish not only plays a significant role in maintaining a healthy aquatic environment, it is also a part of the food chain. Although Malaysia is known to have a high diversity of fish [6], their current status and the total number of species found are left to much argument and speculation. Moreover, the current practice of river dredging, channelization and riparian clearing do not pay heed to the requirement of fish in terms of river habitats. All efforts to improve the hydrology of river to mitigate against floods only accelerate the destruction of fish habitats. With little or no information on fish requirement, the problem is of little or no concern to those involved. For example, removing the natural vegetation of the riparian zone often results in the collapse of the embankment [7]. When water flow is enhanced by channelization, a downstream passage is duly hastened, often resulting in very low water retention during drought. As a result, many fish species are endangered due to the degradation of their habitat and river water quality. Therefore, this study is to determine the status of fish abundance in the rivers as affected by different type of land uses. The study is also conducted to update the fish diversity of selected rivers in Johor. To date, there are limited documented studies on the freshwater fish species especially in Johor's rivers. It is important to assess the distribution and composition of the fish species in each habitat to ensure that in the long term, the fish population is sustained.

\section{Methods And Materials}

Samples of water and ichthyofauna were collected in 2008 to 2010 from four sampling stations located within the Sungai Endau watershed area in the districts of Kluang, Segamat and Mersing in the state of Johor. Sungai Madek, Sungai Mengkibol, Sungai Dengar and Sungai Ulu Dengar which were selected for the study are in the Order 2 and 3 category 
and are mainly wadeable rivers. These criteria are mainly to enable ease of sampling of fish by using the electro-fisher. In addition, the sites are all within a catchment spread that could be assessed easily.

At each station, six in-situ parameters were determined; temperature, conductivity, dissolved oxygen (DO), $\mathrm{pH}$, turbidity and salinity. A multi-meter probe Model Yellow Springs Instrumentation (YSI) 6920 with 650 MDS Display/ Logger as well as single parameter probe were used for in-situ testing of water quality. Seven parameters of water quality were measured in the laboratory namely biochemical oxygen demand (BOD), suspended solids (SS), phosphate, nitrate and sulphate, chemical oxygen demand (COD) and ammoniacal nitrogen (AN). The results were then checked against the Water Quality Index for river classification, namely from Class I to Class V.

Ichthyofaunal samplings were conducted in situ with the assistance of three assistants, with one wielding the electro-fisher, while two others followed to scoop up stunned fishes. Sampling was conducted for a $500 \mathrm{~m}$ upstream and $500 \mathrm{~m}$ for the downstream reach per sampling station by wading from downstream to upstream to avoid disturbing the streams' clarity. The handler of the electro-fisher moved on a left to right along the river and back in a zig-zag manner for better coverage for each reach. All stunned fish were scooped up as fast as possible. Drifted fishes caught in the mesh net lower down the sampling reach were also collected. Measurement of total length and weight were conducted immediately after being sampled. All fish caught were identified for species using the standard taxonomic keys following [8] and [9] and the numbers of individual per species were counted. Total length( $\mathrm{TL}$ in $\mathrm{cm}$ ) of each fish was measured using measuring board and the wet weight $(\mathrm{g})$ of each species were collectively taken using a digital balance, model METTLER BD 1201, to the nearest centimetre and gram respectively.

All statistical analyses were completed using Statistical Package for Social Sciences (SPSS) software version 16.0. One-way analysis of variance (ANOVA) was used to determine the statistically significant different of each test. Detailed explanation of each mean analysis among the group was -conducted using post hoc test based on Turkey's test. Level of significance was set at $95 \%$ ( $\mathrm{p}<0.05)$ to reject null hypothesis. In the study null hypothesis was assumed as there will be no difference between group at all sampling stations.

\section{RESUlt AND DiscUSSION}

\section{A. Species Composition}

A total of 1124 adult and juvenile individuals, representing 35 species from 13 families were collected in the four rivers of Johor. The highest number of fish were collected at Sungai Dengar station (376 individuals) followed by Sungai Ulu Dengar (306 individuals), Sungai Madek (238 individuals) and Sungai Mengkibol (204 individuals). However, no significant differences were found between stations for the fish abundance as the one way ANOVA shows $\mathrm{p}=0.138, \mathrm{p}>0.05$. Overall, Sungai Ulu Dengar has the highest number of species with 22 species, followed by Sungai Dengar with 21 species and Sungai Madek with 19 species (Table I). The lowest number of species was recorded at Sungai Mengkibol with 11 species.

TABLE I

FISH CHECKLIST OF SELECTED RIVERS IN JOHOR

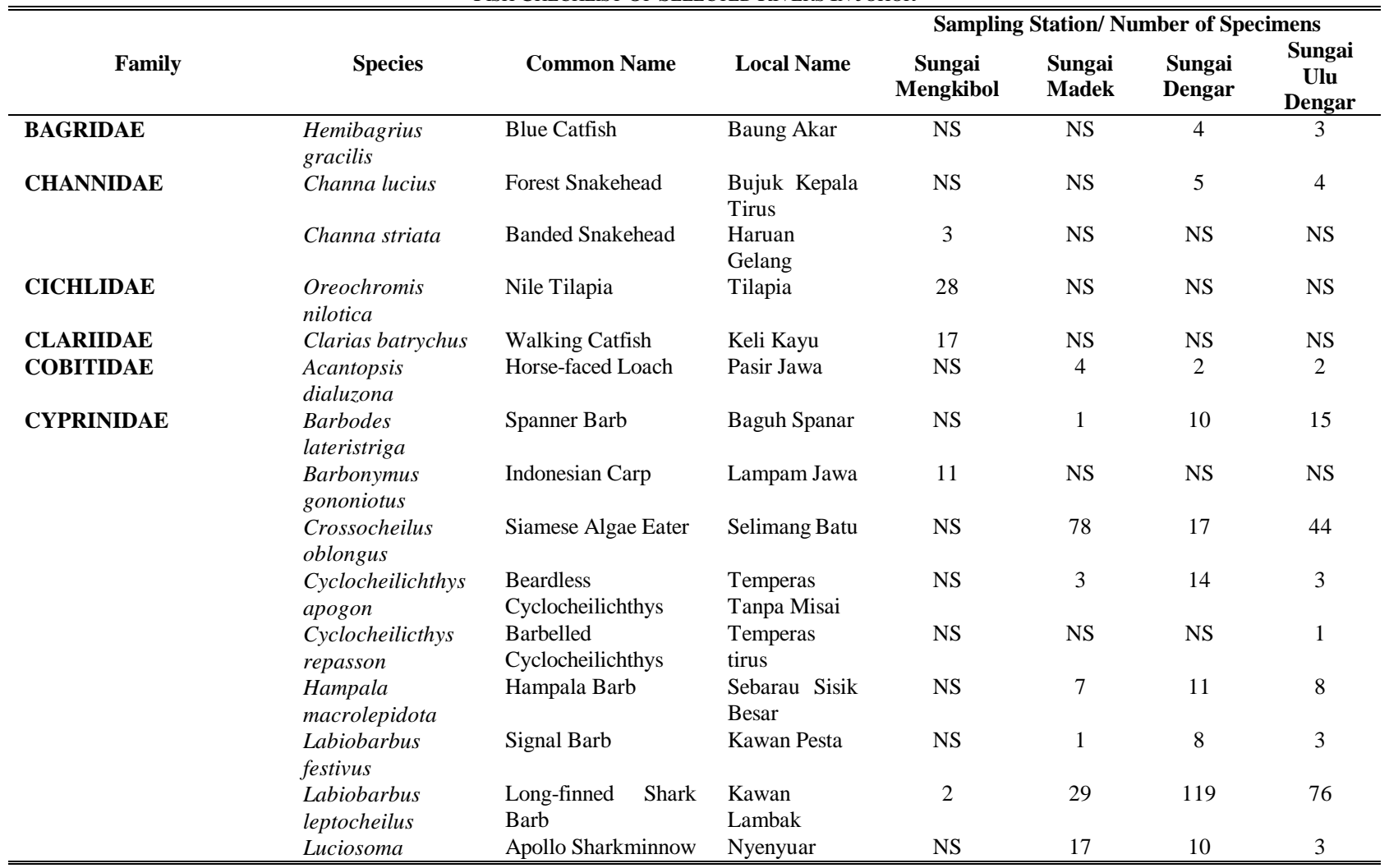




\begin{tabular}{|c|c|c|c|c|c|c|c|}
\hline & $\begin{array}{l}\text { setigerum } \\
\text { Mystacoleucus } \\
\text { marginatus }\end{array}$ & $\begin{array}{l}\text { Procumbant-spined } \\
\text { Barb }\end{array}$ & $\begin{array}{l}\text { Misai } \\
\text { Sia Jawa }\end{array}$ & NS & 19 & 22 & 22 \\
\hline & $\begin{array}{l}\text { Neolissocheilus } \\
\text { soroides }\end{array}$ & Copper Mahseer & $\begin{array}{l}\text { Tengas Hijau } \\
\text { Kuning }\end{array}$ & NS & 2 & NS & NS \\
\hline & $\begin{array}{l}\text { Osteochilus } \\
\text { flavicada }\end{array}$ & $\begin{array}{l}\text { Black-banded } \\
\text { Sharkminnow }\end{array}$ & $\begin{array}{ll}\text { Rong Sirip } \\
\text { Kuning }\end{array}$ & NS & 25 & 69 & 2 \\
\hline & $\begin{array}{l}\text { Osteochilus } \\
\text { microcephalus }\end{array}$ & Bonylip Barb & $\begin{array}{l}\text { Rong Kepala } \\
\text { Kecil }\end{array}$ & NS & NS & NS & 18 \\
\hline & $\begin{array}{l}\text { Osteochilus } \\
\text { vittatus }\end{array}$ & Silver Sharkminnow & Rong Terbul & 3 & 5 & 4 & 4 \\
\hline & $\begin{array}{l}\text { Osteochilus } \\
\text { waandersii }\end{array}$ & Hard-lipped barb & $\begin{array}{l}\text { Rong } \\
\text { waandersii }\end{array}$ & NS & 31 & 24 & 24 \\
\hline & $\begin{array}{l}\text { Parachela } \\
\text { oxygastroides }\end{array}$ & Knife Barb & $\begin{array}{l}\text { Lalang Sirip } \\
\text { Pendek }\end{array}$ & NS & NS & 5 & 7 \\
\hline & $\begin{array}{l}\text { Rasbora } \\
\text { dusonensis }\end{array}$ & Yellowtail Rasbora & $\begin{array}{l}\text { Seluang } \\
\text { Duson }\end{array}$ & 2 & 2 & 20 & 10 \\
\hline & Rasbora elegans & Two-spot Rasbora & $\begin{array}{l}\text { Seluang } \\
\text { Tompok } \\
\text { Tengah Badan }\end{array}$ & NS & 1 & 6 & NS \\
\hline & $\begin{array}{l}\text { Systomus } \\
\text { binotatus }\end{array}$ & Two-spot Barb & $\begin{array}{l}\text { Tebal Sisik } \\
\text { Tompok }\end{array}$ & NS & 2 & 9 & 9 \\
\hline GOBIIDAE & $\begin{array}{l}\text { Oxyeleotris } \\
\text { mamorata }\end{array}$ & Marbled Goby & Ketutu, Ubi & 1 & NS & NS & NS \\
\hline \multirow[t]{2}{*}{ HEMIRAMPHIDAE } & $\begin{array}{l}\text { Hemirhamphodon } \\
\text { pogonognathus }\end{array}$ & Forest Halfbeak & $\begin{array}{l}\text { Jolong-jolong } \\
\text { Rimba }\end{array}$ & NS & NS & NS & 1 \\
\hline & $\begin{array}{l}\text { Xenotodon } \\
\text { cancilla }\end{array}$ & Freshwater Garfish & $\begin{array}{l}\text { Todak Air } \\
\text { Tawar }\end{array}$ & NS & NS & 1 & 1 \\
\hline LORICARIIDAE & $\begin{array}{l}\text { Hypostomus } \\
\text { plecotomus }\end{array}$ & Suckermouth Catfish & $\begin{array}{l}\text { Ikan } \\
\text { Bandaraya }\end{array}$ & 88 & NS & NS & NS \\
\hline \multirow[t]{3}{*}{ MASTACEMBELIDAE } & $\begin{array}{l}\text { Macrongathus } \\
\text { maculatus }\end{array}$ & $\begin{array}{l}\text { Buff-backed Spiny } \\
\text { Eel }\end{array}$ & Tilan Coklat & NS & 1 & NS & NS \\
\hline & $\begin{array}{l}\text { Mastacembelus } \\
\text { unicolor }\end{array}$ & Spotted Spiny Eel & Tilan Hitam & NS & 2 & NS & NS \\
\hline & $\begin{array}{l}\text { Mastacembelus } \\
\text { favus }\end{array}$ & Tyre-track Spiny Eel & Tilan Batik & NS & 2 & 1 & NS \\
\hline POECILIDAE & Poecilia sphenops & Short-finned Molly & $\begin{array}{ll}\text { Molly } & \text { Sirip } \\
\text { Pendek } & \end{array}$ & 46 & NS & NS & NS \\
\hline SISORIDAE & $\begin{array}{l}\text { Glythothorax } \\
\text { callopterus }\end{array}$ & $\begin{array}{l}\text { Wrinkle-bellied } \\
\text { Catfish }\end{array}$ & $\begin{array}{l}\text { Kenderap } \\
\text { Kecil }\end{array}$ & NS & NS & NS & 1 \\
\hline SYNBRANCHIDAE & $\begin{array}{l}\text { Monopterus } \\
\text { javanensis }\end{array}$ & Swamp Eel & Belut Paya & 1 & NS & 1 & 1 \\
\hline
\end{tabular}

Families that dominated were Cyprinidae with 19 species $54.29 \%$ ), followed by Mastacembelidae with three species (8.57\%), Channidae and Hemiramphidae with 2 species each (5.71\%) (Table II). The other families were represented by one species each from Bagridae, Cichlidae, Claridae, Cobitidae, Gobiidae, Loricariidae, Poecilidae, Sisoridae and Synbranchidae (2.86\%). Among the families, the Cyprinidae comprised the highest number of species as they are the most common species found in Malaysia's river. This was similar with previous studies recorded by [10] and [11] in Sungai Pahang and Sungai Perak respectively. The dominance of Cyprinidae could probably be due to the high adaptive variability and availability of extensive heterogeneous habitat structure in Malaysia's river. There were three exotic species recorded namely Oreochromis nilotica, Hypostomus plecotomus and Poecilia sphenops. [12] reported that the exotic fish, Hypostomus plecotomus or also known as Suckermouth Catfish have successfully invaded water bodies of various countries worldwide including Malaysia, Singapore, Philippines, Japan and Europe. This species is widely used as a natural method to remove algae in an aquarium. Invasion of the exotic fish species has resulted in extinction of native species, predation, genetic degradation and disruption of the receiving environment [13].

TABLE II

PERCENTAGE COMPOSITION OF Fish FAMILIES AT SAMPLING STATION

\begin{tabular}{lc}
\hline \multicolumn{1}{c}{ Family } & Composition $(\%)$ \\
\hline BAGRIDAE & 2.86 \\
CHANNIDAE & 5.71 \\
CICHLIDAE & 2.86 \\
CLARIIDAE & 2.86 \\
COBITIDAE & 2.86 \\
CYPRINIDAE & 54.29 \\
GOBIIDAE & 2.86 \\
HEMIRAMPHIDAE & 5.71 \\
LORICARIIDAE & 2.86 \\
MASTACEMBELIDAE & 8.57 \\
POECILIDAE & 2.86 \\
SISORIDAE & 2.86 \\
SYNBRANCHIDAE & 2.86 \\
\hline \hline
\end{tabular}

\section{B. Water Quality}

Table III shows the concentration of each parameter and river classification based on Malaysia Water Quality Index (MWQI). Overall, Sungai Mengkibol has been classified under Class III of MWQI, whereas Sungai Madek, Sungai Dengar and Sungai Ulu Dengar can be classified as Class I river. An 
earlier study conducted by [14] indicates that Sungai Mengkibol and Sungai Dengar are under Class IV and II respectively. Poor water quality recorded in Sungai Mengkibol is probably associated with anthropogenic contamination (as Sungai Mengkibol is located in Kluang town), compared with Sungai Madek and Sungai Dengar which are located in a logging area and palm oil plantation respectively. Moreover, degradation of water quality at Sungai Mengkibol could have been influenced by industrial waste water discharges and agricultural activities located upstream of the sampling station [15].

TABLE III

AVERAGE WATER QUALITY AND COMPARISON WITH MALAYSIA WATER QUALITY INDEX (MWQI)

\begin{tabular}{|c|c|c|c|c|}
\hline \multirow{2}{*}{$\begin{array}{l}\text { Parameter/ Water } \\
\text { Quality Index }\end{array}$} & \multicolumn{4}{|c|}{ Sampling Station } \\
\hline & Mengkibol & Madek & Dengar & Ulu Dengar \\
\hline $\begin{array}{l}\text { Dissolved oxygen, } \\
\mathrm{mg} / \mathrm{L}\end{array}$ & $3.37 \pm 0.62$ & $7.80 \pm 0.47$ & $7.30 \pm 0.67$ & $7.59 \pm 0.43$ \\
\hline Temperature, ${ }^{\circ} \mathrm{C}$ & $32.06 \pm 2.09$ & $25.37 \pm 0.89$ & $25.64 \pm 0.78$ & $25.85 \pm 1.22$ \\
\hline Turbidity, NTU & $65.22 \pm 26.75$ & $17.14 \pm 9.63$ & $6.02 \pm 1.12$ & $3.15 \pm 1.01$ \\
\hline MWQI & Class III & Class I & Class I & Class I \\
\hline
\end{tabular}

\section{Relationship Between Water Quality With Fish} Abundance

Figure 1 shows the relationship of water quality parameters; dissolved oxygen (DO), turbidity and temperature with number of fish collected at sampling stations. There was a quite significant correlation $\left(\mathrm{r}^{2}=0.63\right)$ observed between DO and number of fish. High number of fish was collected at high concentration of DO. Sungai Mengkibol has the lowest DO content which categorized under Class III compared with other rivers. However, the fish abundance between rivers was slightly similar. The low DO in Sungai Mengkibol might be due to high organic enrichment contributed by human activity. Hence, only tolerable species were found abundantly in Sungai Mengkibol. Moreover, the number of fish also influenced by water turbidity as $r^{2}=0.67$. Among the sampling station, again the water of Sungai Mengkibol is murkier than others. The presence of suspended particles like silt, clay, organic matter or plankton might cause high turbidity in the river [16].

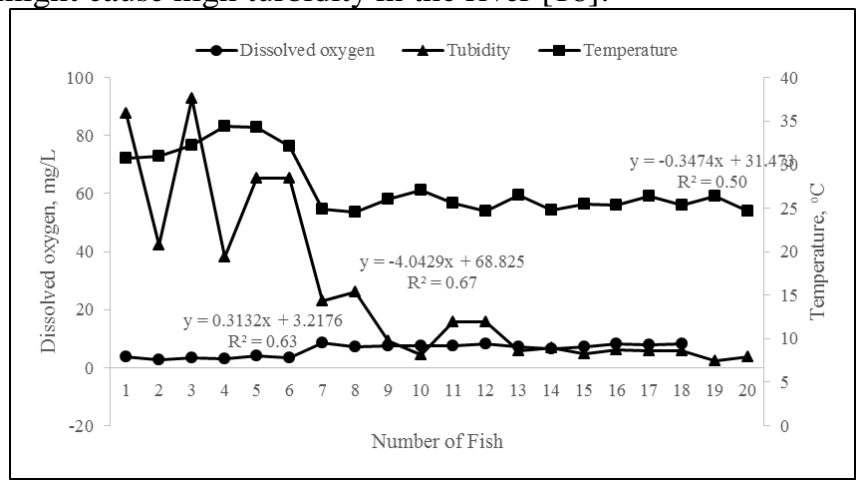

Fig. 1. Relationship between water quality parameters with fish abundance

The low water quality at Sungai Mengkibol is only suitable to highly tolerant fish like Suckermouth Catfish and Short-finned Molly. The Suckermouth Catfish is a non-native fish that possess remarkable ability to adapt in poor environmental levels. They become the dominant fish in tropical areas owing to their respiration accessory with diverticula of the gastrointestinal tract, hard scales, and lack of predators [17].
However, their presence altered invertebrate community composition in leaf packs and produced ecosystem engineering effects by altering benthic habitat [18].

Although the fish abundance among the rivers was slightly similar, the river with good water quality (Class I river) like Sungai Ulu Dengar and Sungai Dengar were inhabited by a high number of species. Most of the species like Hampala Barb, Marbled Goby and Blue Catfish have high economical values and also one good source of protein for human consumption. Several studies have reported that the Suckermouth Catfish tend to accumulate high concentrations of lead and cadmium, and hence, not recommended for human consumption [17]; [19]. Generally, river water quality is controlled by human activities and natural factors like physical characteristics at both the river and watershed scales [20]. Hence, further studies on relationship between river characteristics and fish diversity are essentially needed.

\section{IV.CONCLUSION}

This study has shown that there was no significant difference of fish abundance at river categorized as Class III (Sungai Mengkibol) and Class I rivers (Sungai Ulu Dengar, Sungai Dengar). However, high species diversity was observed at river with good water quality (Sungai Ulu Dengar, Sungai Dengar). Factors like human activities and river characteristics might greatly influence the river quality and affect the function of the river as a habitat. Hence, further study is required to conduct in order to improve understanding on importance of river characteristics to the fish species. Often, research studies in Malaysia involve either physical or biological characteristics without being associated with the fish's habitat condition [21], [11].

\section{REFERENCES}

[1] M. Firouzi, "Hydrologic analysis for Southern Malaysia using modeling and analytical probabilistic approach". M.S. Thesis. Universiti Teknologi Malaysia. 2011

[2] H. Juahir, Zain, S. M., Yusoff, M. K., Hanidza, T. T. T., Armi, A. S. M., Toriman, M. E. and Mokhtar, M.. "Spatial water quality assessment of Langat River (Malaysia) using environmetric techniques. Environmental Monitoring Assessment, vol. 173, pp. 625-641, 2011. http://dx.doi.org/10.1007/s10661-010-1411-x

[3] M. J. Kennish, "Environmental threats and environmental future if estuaries". Environmental Conservation, vol. 29, pp. 78-107, 2002. http://dx.doi.org/10.1017/S0376892902000061

[4] B. R. Jha, Fish Ecological Studies and Its Application in Assessing Ecological Integrity of Rivers in Nepal. Doctor Philosophy, Kathmandu University, Nepal. 2006.

[5] P. Moyle, K. Crain, K. Whitener, and J. F. Mount, J. F. "Alien fishes in natural streams: Fish distribution, assemblages structure, and conservation in the Cosumnes River, California, U.S.A". Environmental Biology and Fisheries, vol. 68, pp. 143-162, 2003. http://dx.doi.org/10.1023/B:EBFI.0000003846.54826.a6

[6] V. C. Chong, P. K. Y. Lee, and C. M. Lau, "Diversity, extinction risk and conservation of Malaysia fishes". Journal of Fish Biology, vol. 76, pp.2009-2066, 2010.

http://dx.doi.org/10.1111/j.1095-8649.2010.02685.x

[7] S. K. Mishra, U. K. Sarkar, B. K. Gupta, S. P. Trivedi, V. K. Dubey, and A. Pal, "Pattern of freshwater fish diversity, threats and issues of fisheries management in an unexplored tributary of the Ganges Basin, Northern India". Journal of Ecophysiology Occupational and Health, vol. 11, pp. 149-159, 2011.

[8] A. K. M. Mohsin, and M. A. Ambak, Freshwater Fishes of Peninsular Malaysia. Penerbit Universiti Pertanian Malaysia, Malaysia, 1983. 
[9] S. C. Hua, "A field guide to the fish of Tasek Bera Ramsar Site, Pahang Malaysia". Petaling Jaya: Wetland International Malaysia Programme. (2002).

[10] A. R. Zulkafli, M. N. A. Amal, S. Shohaimi, A. Mustafa, A. H. Ghani, S. Hashim, M. I. Anuar, and M. P. Hasfairi, "Length-weight relationships of 20 fish species from Pahang River, Maran District, Pahang, Malaysia”. Journal of Applied Ichthyology, vol. 31, pp. 409-410, 2015. http://dx.doi.org/10.1111/jai.12666

[11] Z. H. Hashim, R. Y. Zainuddin, A. S. R. M. Shah, S. A. M. Sah, M. S. Mohammad, and M. Mansor, "Fish checklist of Perak River, Malaysia". Journal Species Lists and Distribution, vol. 8, pp. 408-413, 2012. http://dx.doi.org/10.15560/8.3.408

[12] A. Bijukumar, R. Smrithy, U. Sureshkumar, and S. George, "Invasion of South American Suckermouth Armoured Catfishes Pteygoplichthys spp. (Loricariidae) in Kerala, India- A case study". Journal of Threatened Taxonomy, vol. 7(3), pp. 6987-6995, 2015. http://dx.doi.org/10.11609/JoTT.o4133.6987-95

[13] K. A. Rahim, Y. Esa, and A. Arshad, "The influence of alien fish species on native fish community structure in Malaysia waters". Kuroshio Science, vol. 7, pp. 81-93, 2013.

[14] H. Halim, "Water Quality and Fish Habitat Assessment of Rivers in Johor (Sungai Dengar, Sungai Tui and Sungai Mengkibol)," M.S. thesis, Universiti Teknologi Malaysia, 2009.

[15] E. A. Rak, Ahmad-Abas, Said, S. Ismid, and M. Mohamad, "Benthic macroinvertebrate composition and diversity in the Mengkibol River, Kluang, Johor, Malaysia", presented at The 7th IMT-GT UNINET and the 3dr Joint International PSU-UNS Conference on Bioscience for the Future. Songkla University, Thailand, 2010.

[16] J. Yisa, T. and Jimoh, "Analytical studies on water quality index of River Landzu", American Journal of Applied Sciences, vol. 7, pp. 453-458, 2010. http://dx.doi.org/10.3844/ajassp.2010.453.458

[17] Y. Ernawati, "The analysis of the concentration of heavy metals cadmium, mercury and lead in the flesh of Suckermouth Catfish (Pterygoplichthys pardalis) in Ciliwung River, Indonesia", International Journal of the Bioflux Society, vol. 7, pp. 33-43, 2014.

[18] S. E. Scott, C. L. Pray, W. H. Nowlin, and Y. X. Zhang, "Effects of native and invasive species on stream ecosystem functioning". Aquatic Sciences, vol. 74, pp. 793-808, 2012.

http://dx.doi.org/10.1007/s00027-012-0263-6

[19] Asnawi, O. Sjofjan, E. Sudjarwo, and Suyadi. "Potency of Sapu-sapu Fish (Hypostomus plecostomus) as feed supplement for local ducks". International Journal of Poultry Science, vol. 14, pp. 240-244, 2015. http://dx.doi.org/10.3923/ijps.2015.240.244

[20] S. Li, S. Gu, W. Liu, H. Han, and Q. Zhang, "Water quality in relation to land use and land cover in the Upper Han River Basin, China, Catena, vol. 75, pp. 216-222, 2008. http://dx.doi.org/10.1016/j.catena.2008.06.005

[21] M. M. Isa, C. S. M. Rawi, R. Rosla, S. A. M. Shah, and A. S. R. M. Shah, "Length-weight relationships of freshwater fish species in Kerian River Basin and Pedu Lake". Research Journal of Fisheries and Hydrobiology, vol. 5, pp. 1-8, 2010. 